\title{
USING THE INTERNET IN A LANGUAGE CLASSROOM: A CASE STUDY
}

Samantha Hannig and Gary Barkhuizen Rhodes University

This article reports on a case study which investigated the use of the internet; specifically the World Wide Web, to complete a literary-based project on the film Shakespeare in Love. Grade 10 high school learners were observed during their Information Technology (IT) classes and they were asked to complete a questionnaire on their perceptions of the success of the project. It was found that the project was not well received. Lack of communication between the IT teachers and the English teachers resulted in uncertainty on the part of the learners about what to do. The majority of the learners felt that the project did not enrich their experience of studying the film.

In hierdie artikel word 'n gevallestudie beskryf wat handel oor die ervarings van 'n Groep graad 10-hoërskoolleerders met die internet. Hulle moes die World Wide Web gebruik om 'n letterkundeprojek oor die film Shakespeare in Love te doen en is waargeneem tydens hulle Infromasietegnologieklasse. Hulle is ook gevra om 'n vraelys te voltooi oor hulle persepsie van die sukses van die projek. Daar is bevind dat die leerders nie van die projek gehou het nie. Gebrekkige kommunikasie tussen die Informasietegnologie-onderwysers en die Engelsonderwysers het veroorsaak dat die leerders nie presies geweet het wat van hulle verwag word nie. Die meeste leerders was van mening dat die projek nie verrykend wat ten opsigte van die bestudering van die film nie.

\section{INTRODUCTION}

People make use of all sorts of technology to communicate: from the simple wire telephone to more recent innovations such as cell-phones, beepers, e-mail and the internet. With these technological advances, especially in the computer industry, communication is more convenient and a lot faster. In the work-place and at universities and colleges there is often easy access to the tools available on computers, but many school leavers start work or further education with little or no knowledge of how to make use of these tools. It makes sense, therefore, to introduce these learners to computer-based education at an earlier stage while they are still at school.

This article reports on a research project which explored the use of the internet in language classes at high school. We acknowledge from the start that there are many schools in South Africa which do not have access to the internet, or even to computers for other uses such as word processing. However, there are more and more schools which do. Our research investigated two such schools. More specifically, we looked at how the internet was used in four Grade 10 English First Language classes. The aim of the learners' work was to make use of the internet in order to complete a poster project on the film Shakespeare in Love, and the aim of the research project was to discover the learners' perceptions of their experience of this work. These findings 
are integrated with data obtained through conversations with teachers and classroom observations.

\section{USING THE INTERNET IN LANGUAGE TEACHING}

Discussions and research on using the internet in language teaching tend to focus on the teaching and learning of English in second and foreign language contexts. There are, however, a few cases where other languages are the target of instruction (see below). This section discusses a few examples of this work which takes place in language classes, and, where appropriate, in the classes of other school subjects. Much of the literature portrays the use of the internet in a positive light, mentioning only a few problems. A few more will be raised at the end of this section.

As many people now know, the internet consists of many computers located throughout the world which are connected together as a worldwide network (Carrier, 1997). Because of this network, computers can communicate with each other, regardless of their geographical position. One can immediately see the attraction for language teachers. They make use of the internet because it plays a role in facilitating communication (Barron \& Ivers, 1998; Ganderton, 1996; Serim \& Koch, 1996), often between different and very distant language communities.

Furthermore, there is the widespread belief that activities on the computer aid language learning (Carrier, 1991). It is also believed that when learners work together during computer-based activities, either in pairs or in groups, they make more progress in developing their spoken communication skills than when working alone (Carrier, 1991, 1997). In addition to this, Lee et al. (1999) believe that typically, teachers want to introduce new ways of teaching so that learners will get the maximum benefits from their experiences in class and that it is the internet which allows for 'a more efficient and interesting way of "imparting knowledge". According to Meagher (1995) and Serim \& Koch (1996), teachers are nowadays encouraged to teach in a way that is not based solely on rote learning (see, for example, teaching approaches promoted in Curriculum 2005). Instead, they are urged to enable their learners to look at different theories, solve real problems and participate in discussions. Using the internet is one way that allows learners to construct their own knowledge. The learning environment is broadened and the barriers to accessing information are eliminated (Serim \& Koch, 1996). The learners can go beyond the classroom context and connect with different people on a national and international level, accessing up-to-date information (see also Relan \& Gillani, 1997).

Related to this is the affective factor of motivation, a 'key factor in successful language learning' (Mckenzie, 2000:34). Teachers try to implement new teaching methods to sustain both their learners' interest and to encourage involvement in the language classroom (Mckenzie, 2000). Barron \& Ivers (1998) state that internet use is beneficial to the learners because it increases motivation and positive behaviour. Meagher (1995) has found that 'the more relevant to the real world the (computer-based) projects are, the more motivated are the students to research, collaborate, and learn'. Serim \& Koch (1996) support the idea that if learners can explore the real world, they will be more motivated to develop their knowledge.

Another reason why teachers use the internet is so that they can spend more time on actual faceto-face interaction in their classes. For example, the Spanish Department at the University of Illinois has put Spanish syntax rules and vocabulary lists online and students are expected to 
work through these on their own. The teachers are then free to spend time on communicative group work and one-on-one instruction with individual students during class time (Bowers, 1999).

\subsection{Tools available on the internet}

There are numerous tools or facilities available on the internet that are useful to language teachers. Electronic mail (e-mail) is the most popular way to communicate on the internet (Sperling, 1997) because it allows the user to send and receive typed messages over the internet to anyone, anywhere, who has an e-mail address. It is relatively easy to use and its immediacy has made it an effective method of international communication (Ganderton, 1996). E-mail is useful in language education because teachers can collaborate with other language teachers all over the world. Distance becomes irrelevant and therefore teachers can easily share ideas, discuss and plan courses, materials, tests and projects with other teachers (Davies, 1998).

One popular idea for using e-mail in language teaching is the creation of keypals (Ganderton, 1996; Sperling, 1997). A keypal is the computer equivalent of a penpal. By writing regular emails to a keypal, language development is promoted. In Mexico City, the Universidad Nacional Autonoma de Mexico (UNAM) conducted research which showed that 'communication with people actually living in countries where the language is spoken improves the quality of student's work' (Meagher, 1995). This view is supported by Davies: 'Having a correspondent, or several correspondents, close at hand and away from the student-teacher relationship, reduces affective barriers and may considerably facilitate learning' (Davies, 1998). Because replies can be sent and received quickly, students remain motivated to stay in touch with their keypals.

Other internet tools that can enhance language learning are mailing lists and discussion groups. Subscribing to a mailing list gives one regular access, via e-mail, to daily news or electronic magazines of particular interest groups (Ganderton, 1996). This format also allows participation in discussion groups: messages are posted and sent out to subscribers who then respond. The response is then distributed to all the subscribers, and so the discussion continues. Learners who join mailing lists can keep up with current news and learn new vocabulary (Sperling, 1997). In the traditional classroom it is usually the teacher who says when a learner may speak and what the learner can speak about. With mailing lists, the learners do the 'talking' and they convey their own ideas and opinions. Consequently, they become more actively involved in the creation of their knowledge (Lee et al., 1999). Furthermore, they can continue with a discussion outside of their class hours; learning need not be hindered by time (McCormack \& Jones, 1998). This is useful particularly for those learners who are really interested in a topic and who wish to discuss it further and in more detail. Learning, therefore, can be seen as an ongoing process and not a static process allocated to set lesson times (Carrier, 1997).

There are also facilities on the internet, such as Internet Relay Chat (IRC) which people use to communicate in real time. According to Ganderton (1996), learners find these 'chat' channels motivating and good 'conversation' practice. IRC is written communication in dialogue format and because "the communication in IRC is ... with real native speakers, it is very helpful in enhancing students' communicative competence and raising awareness of key aspects of language needed in communication' (Mathieson, in Ganderton, 1996). The problem with these online communication channels is that they are open to everyone and, as a result, there is no ringmaster (Bowers, 1999). Once again the teacher has no control over who joins the 'conversation' or over what is spoken about (Ganderton, 1996). Although IRC does aid language learning, often irrelevant or inappropriate material is introduced which might be inappropriate 
to schools users in language classes, such as pornography or foul language.

The World Wide Web is one of the most accessible tools for people to use and, at the same time, is an important 'economic and democratic medium of learning and teaching' (Relan \& Gillani, 1997:5). Information is provided in a colourful and often graphic format, and it is possible to change from site to site simply by clicking on icons and underlined or highlighted text. The Web is thus relatively easy to use. Ganderton (1996) states that, for language learners, use of the Web can enhance knowledge of the target language and culture. For example, learners can keep up with current events in the target language community by accessing online newspapers in that language. They can also contribute to the information available on the Web, thus articulating their own opinions and understandings (Relan \& Gillani, 1997; see also Barron \& Ivers, 1998; Carrier, 1997; McCormack \& Jones, 1998; Serim \& Koch, 1996).

\subsection{Problems with using the internet in language education}

Although the internet is useful as a teaching tool, it is important that both the teachers and learners realise that there are limitations; for example, accessibility. Although, in some parts of the world, much money is being spent on technology, teachers are not making use of the facilities available to them. This is because English teachers tend to have 'normal' classrooms and if they do want to use computer-based projects, they need to book the laboratories well in advance (Crampton, 1999). There may also be competition for the time, so the teachers only get to use the labs once in a while. In other cases, some learners do not even have access to teachers or electricity, let alone an expensive commodity like the internet (McCormack \& Jones, 1998). There is also the problem of knowing how to use the internet effectively. Crampton (1999) remarks that 'teachers are often less computer literate than their pupils', but it is the teachers who need to design or create projects for the learners. They (and their learners) need training on how to use the internet, and this can be a costly and time-consuming process (McCormack \& Jones, 1998).

Another very significant problem is the validity of the information obtained from the internet. Almost anyone can post information on the Web, or talk on IRC. Because of this, one needs to be wary of how reliable the information is. It is for these reasons that technology, or educational software, should not be seen as a substitute for textbooks or teachers. Instead, it should be used in conjunction with the more traditional methods and tools (McCormack \& Jones, 1997). The goal, according to Markee (in an interview with Bowers, 1999), is to 'exploit the strengths of both face-to-face interaction and the technology, and to mould the two together into a complementary package' (Bowers, 1999:305).

This review of the literature has described a number of tools which are available on the internet for use in language classes, and has at the same time noted one or two problems which may be encountered. In the next section, we report on a case study where there was an attempt to 'enrich current teaching styles by augmenting classes with aspects of Internet-based learning' (French, Hale, Johnson \& Parr,1999:1).

\section{RESEARCH METHODS}

The participants in the study were two Grade 10 English classes at a relatively small, private, allboys school in the Eastern Cape and two Grade 10 English classes from the all-girls sister school. As part of their English set work, these learners studied the film Shakespeare In Love. 
The schools worked closely together, sharing in many cases the same educational facilities. An Information Technology (IT) project was designed which required the learners from both schools to use the World Wide Web to find information about the movie and then to present a poster based on this information. The main objective of the exercise was to enrich or augment (see Bett, French, Farr \& Hooks, 1999) the learners' literary experience of the film. Several data-collection procedures were used to see if this in fact happened.

Several people involved with the project were interviewed: the heads of the IT departments at both the boys and girls schools, as well as the English teacher who set up the project. Contact with these people was established via electronic mail and telephone before meeting in person. It was useful talking to them in order to determine why they were using the internet and what they expected their learners to gain from the project.

The four Grade 10 English classes were observed to see how the projects were progressing and what the learners did during the allocated periods. It was during these observation sessions, which were done over a period of two weeks, that the questionnaires were distributed (see appendix A). In each class there were about twenty learners. After the questionnaires were completed during class time, 10 questionnaires were randomly selected from each class, giving a total of 40 . When analysing the data, the questionnaires from the two girls' classes were combined, and those from the two boys' classes were combined. The girls' and boys' questionnaires, however, were at first analysed separately, and then conclusions regarding the opinions of the IT project were drawn from the combination of the findings. These findings were conflated with what was observed in the English classes and the comments obtained from the teachers during their interviews. The results of this are presented in the next section.

The researchers were non-participants during classroom activities. We were neither involved in the planning of lessons nor in any formal assessment of the work done. Our role was merely to record events as they unfolded and perceptions as they developed through classroom observations, conversations with teachers and responses from the learners to the questionnaire.

\section{FINDINGS}

The responses from the questionnaires are presented and discussed in some detail in this section. Numbers of learners who answered Yes or No to the relevant questions are presented, and reasons for their answers are provided in their own words. For easier reading, some of these excerpts have been slightly edited.

\subsection{Responses from the girls}

The average age of the 20 girls was 15.2 years. Of these, 13 had done Computer Studies as a subject some time during their time at school, while 7 had not done Computer Studies at all before. Most of the girls (19) were interested in computers in general (question 5). Only 1 answered No to this question and thus did not answer the related question (question 6). The results for question 6 are therefore calculated out of 19 . 
Table 1: Computer tools used by the girls (Response to question 6).

\begin{tabular}{|l|l|}
\hline \multicolumn{1}{|c|}{ Tools } & \multicolumn{1}{|c|}{$\begin{array}{c}\text { Number of girls } \\
(\mathbf{n}=19)\end{array}$} \\
\hline E-mail & 17 \\
\hline World Wide Web & 12 \\
\hline Word Processors & 10 \\
\hline Computer games & 9 \\
\hline Delphi (for programming) & 2 \\
\hline Music (to download or play) & 2 \\
\hline Chat rooms & 1 \\
\hline
\end{tabular}

Much of the literature reviewed (see Ganderton, 1996; Sperling, 1997) indicated that the most popular and the most easily accessible tools available on the internet are e-mail and the Web. The results shown in Table 1 support this.

With regard to question 7, the majority of the girls (19) were extremely positive about the movie Shakespeare In Love. Their responses were as follows: 'Enjoyable, cleverly done' (6 others had similar responses); 'Very good' (3 girls said this); 'It is a very interesting movie' (2); 'A brilliant way of bringing true love to our eyes and great poetry to our ears' (2); 'It was enchanting'; 'I loved it, it's clever, comical and romantic' (2); 'A powerful movie about the power of words' and 'I thought it was a very appropriate movie for us Grade 10 s to study at school'. The one girl who did not enjoy the movie had this response: 'it sucked and it was boring'. The reason we asked about the learners' impression of the movie was to determine if it affected their attitudes towards the project. One would think that if they enjoyed the movie then they would have a more positive attitude to doing the project. However, this is not the case, as can be seen from the next set of results, the answers to question 8 .

Fifteen girls had overall negative feelings about the project: 8 said that they 'didn't think it's a good idea'; 3 said that it was 'stupid and a waste of time'; 3 girls ( 2 of whom had not done computer studies and 1 who was not interested in computers) said that they were 'not computer literate to do what they're asking' and so 'wouldn't have a clue how to do it'. Three girls were initially neutral: 'It was okay' and 'it's alright', while 2 girls thought the project was a good idea, but time-consuming: 'It is a good idea but I was not very appreciative as we have got lots of other work too like Biology projects'.

For some of the girls, it appears as though their lack of computer skills did affect their attitudes towards the project. If the learners do not have the ability to do something, but are forced to in order to get marks, it is likely that they will resent doing the task, feeling frustrated and inadequate. These negative feelings were evident during observations of the girls at work. Some of them appeared to know what the English teachers wanted, but did not know how to go about it. The IT teacher was, however, in the computer room at all times during the lesson. She appeared very enthusiastic and worked with the girls, helping them with search engines, giving them web-sites and demonstrating examples, like how to have writing with a watermark in the 
background. The problem was, though, that she could only help one learner at a time, or a few learners who were sitting together. Other learners who had problems had to sit and wait for their turn to confer with the teacher. This is time-consuming for the learner and probably frustrating too since they cannot carry on with their work.

Only 3 out of the 20 girls said that they did not have the necessary skills and were thus negative about the project. According to the IT teacher at the boys' school, the learners' internet skills were adequate and the project was designed in direct relation to the level of their skills. The girls' IT teacher supported this and said that although IT is not a teaching subject that is examinable, computer skills are taught during IT lessons. It was not as if the learners had never before been exposed to computers. For the 3 girls who felt that their computer skills were inadequate, they should perhaps have seen this project as an opportunity to learn more about using the internet.

Questions 10 and 11 asked the learners if their initial feelings towards the project changed, and to give a reason for their answer. Several weeks after the learners were given the project instructions, 4 girls had not yet started. Eleven of the girls remained negative about the project. Their responses were much like their initial responses to question 8: 'I still think it's boring'; 'I still don't have the literacy to do what I want to do with the project'; 'It's extra work'; and, 'I wanted to do other things on the computer in the lesson'.

The opinions of 5 girls changed in the following ways: 3 changed from a negative to a positive view: 'I got into it and had ideas for what I could do'; 'it wasn't that hard' and 'I enjoy looking at all the pictures'. One girl's opinion changed from a neutral to a more positive one: 'I like looking at all the pictures on the internet and it'll help me for my exam'. Another changed from a neutral to a negative view: 'It wasn't that good'.

In response to question 12,8 of the girls said that they did not use their time constructively during the allocated period, which was one period in a six-day cycle. One of these 8 did not say what she was doing in the IT period, but 4 said that they were 'doing other things during the lesson' like programming and working on a biology project. Another response was, 'I feel this period is for e-mailing and surfing the Net', while another girl said, 'I got bored and frustrated because I won't get exactly what I want from the computer, i.e. pictures'.

Another 8 girls said that they did use their time wisely and gave the following reasons: 'I was working on the project' ( 3 girls responded with similar comments); 'I need to use the time I am given otherwise I have to use my free time to do it' (4); and 1 girl said, 'Because I have to get a decent mark'. This latter comment is interesting: the English teacher who created the project said that marks govern motivation. He said that the attitude of many of the learners is that they do not see the purpose of doing something academic unless it is going to count in their results. In spite of this, it appears that this was not a factor for the learners being positive and working hard, as the majority of them saw it as a waste of time. Of the 4 girls who had not yet started, 1 was 'sick in the San...', 2 were searching the internet, but had not found anything concrete for their projects and another was 'not sure where to start'.

With regards to the instructions for the project (see question 13), 8 girls said that there were 'not specific enough guidelines' and so they were 'unsure of what teachers actually want'; there was a bit 'of confusion' because it was 'not organised well enough before giving it to [the learners]'. Five girls felt that the project was too structured in that all the 'posters are going to be very 
similar' because they were all given the same list of Web sites. There was 'not enough freedom' for creativity. Three said that the guidelines were 'fine' or 'okay', and 4 did not answer this question.

The teachers admitted that initially there was not enough communication between the English and IT departments. In one meeting, two English teachers said that they knew nothing about the project. This is somewhat strange, because all the Grade 10 English teachers and the two IT teachers were given a folder which contained the original instructions for the project and a list of relevant web sites. They were also given print-outs of information about the movie Shakespeare In Love from the internet. Those teachers who did not know about the project had probably not read, or at least looked at, the contents of the file. During the observation of the girls' classes, this lack of communication became evident; their IT teacher, for example, did not even know who the girls' English teacher was. She also answered one question raised in class with 'Ask the English department', perhaps because she was unsure of what they wanted the learners to have on their posters.

When it became apparent that there was confusion, the two departments sat down together to revise the original instructions. They determined exact requirements, which were then relayed to the learners. This should have been done right from the start, because by this stage, it was too late. Because the instructions and requirements kept changing, the learners had no motivation and were not interested in the project at all.

Finally, responses to questions 14 and 15, which asked learners if the project enriched their literary experience of the film, indicate that only 4 of the 20 girls felt that it did. Twelve indicated that it did not, and 4 had not started by the time they had filled in the questionnaire. Positive comments included, 'I learnt a lot about using the web', 'I thought more about it and understood things better', and 'The internet has so much information and good pictures to use'. Those who felt that they had not learned much said, 'I just looked at pictures' and 'This project is simply looking up things and copying them straight from the internet'.

\subsection{Responses from the boys}

The average age of the 20 boys was 15.5 years. Twelve boys had done Computer Studies at some stage during school while 8 had not, yet all the boys were interested in computers in general. The results to question 6 are tabulated below. 
Table 2: Computer tools used by the boys (Response to question 6).

\begin{tabular}{|l|l|}
\hline \multicolumn{1}{|c|}{ Tools } & \multicolumn{1}{|c|}{$\begin{array}{c}\text { Number of boys } \\
(\mathbf{n = 2 0})\end{array}$} \\
\hline E-mail & 12 \\
\hline World Wide Web & 16 \\
\hline Word Processors & 5 \\
\hline Computer games & 14 \\
\hline Delphi (for programming) & 1 \\
\hline Music (to download or play) & 0 \\
\hline Chat rooms & 0 \\
\hline
\end{tabular}

Most of the boys (15) liked the movie Shakespeare In Love and responded with, 'A very good movie with a bit of everything, romance, comedy and drama' (4 similar responses), 'Fantastic, the way John Madden produced the film brought the Elizabethan period to life', 'the story was brilliant' (2), and , 'Witty, funny and breath-taking' (2). Three boys were fairly neutral, saying it 'was more or less an average movie', 'I think it was an interesting movie, but a bit stupid', and 'very different from other films'. One of the boys 'disliked the movie a lot' while another 'thought it was a boring woman's movie'.

Their initial feelings about the IT project (question 8) reflected those of the girls. Fifteen had a negative view of the project, with most (11 of these 15) saying that they thought it was "boring and pointless'. The others thought it was 'a total waste of time'. One boy even said that 'it is too hard to find information'. This comment is surprising since all the learners were given a list of a few Web sites featuring the film. They at least had a starting point.

Two of the boys were neutral towards the project, remarking, 'I don't really mind doing it' and 'I think it's a pain, but also gives the opportunity to use [computers] and learn'. The other 3 boys were rather enthusiastic about doing the project as can be seen from the following comments: 'The project is challenging and teaches you to think', 'Excited and adventurous to use my computer skills' and 'Fun, entertaining ... I enjoy putting projects together'.

In response to questions 10 and 11,13 boys did not change their initial opinions. Twelve of these 13 boys still disliked the project; they still found it boring and pointless. One boy resented the project, because it got in the way of 'checking [his] mail and having a free period'. One boy who thought the project was great, remained enthusiastic. Seven boys said their initial feelings about the IT project did change. Six of these became more positive: 'I started enjoying doing it' and 'Well, it was not so boring and got interesting'. One boy became more negative, saying that the project was 'a hassle'.

Ten boys said they did not use the allocated time to do their projects (which, at 2 periods a week of 45 minutes each, was a great deal more than the girls had) because they 'always mess around in this class' or they 'didn't know what to do'. One response was, 'I didn't take it seriously'. This, in spite of the fact that the learners were being graded on the posters that they produced. 
The first time one of the boys' classes was observed, they were indeed 'messing' around. They came into the lab after lunch with no school bags, books or pencil cases and many of them were dressed in sports gear. They sat around in groups talking loudly, playing games, e-mailing or looking up sports on the internet. Because they had always enjoyed doing such activities before in their IT periods, they no doubt resented having to do a serious project for marks. Obviously, when one has a 'free period' and it is taken away, one is going to resent it.

To add to the lack of focus, some of the boys continuously entered and left the lab. This is not usual behaviour in formal English lessons, and since the IT teacher seemed to tolerate this informality and freedom to come and go as the boys saw fit, it contributed to the boys' attitude of not taking the period seriously or getting any work done, as one boy responded in his questionnaire.

However, during the second week of observations, the teacher reminded the boys about the project deadline. Consequently, each learner sat at his own computer and worked on the poster. Another reasons for this attentive behaviour is probably the fact that their teacher was in the room; he went around to each learner and asked to see their poster. The presence of an authoritative figure seemed to make a difference. In the girls' lessons, their IT teacher was present all the time and the lessons were a lot more controlled than the boys' lessons.

The other 10 boys (see question 12) used their time constructively. They 'worked hard' in order 'to get the maximum benefit from time given'. As for the instructions for the project, 4 boys gave irrelevant answers and so these were disregarded. Nine out of 16 thought that there were 'not nearly enough guidelines' and that they were 'not detailed enough'. Four boys responded by saying that 'too much independent research' was required. One of the boys said that the project was too structured: ' if you look at the projects, they are all the same. We weren't allowed enough freedom'. Two thought the structure of the project was fine, saying, 'it did have enough guidelines', and 1 of these added, 'it was nice doing independent research'.

Finally, more of the boys felt positively about the internet project than the girls: 10 , that is, half of them, felt that it enriched their literary experience of the film study, saying, 'It gave me more background information', 'I got to know characters and part of the movie better', and 'I had to read up on the movie myself and put together my own sort of review'. The other 10, however, were less enthusiastic: 'It really doesn't help just to copy and paste a bunch of pictures and quotes onto a poster', and 'I just took pictures off the net and typed a bit'.

\section{DISCUSSION AND CONCLUSION}

The aim of the project was to enrich the learners' literary experience of the film Shakespeare in Love. According to one of the English teachers, word processing skills are vital for writing; these skills are 'the pen of the future'. He feels that technology can be used to improve the writing abilities of the learners. He also said that by integrating IT with the traditional teaching subjects, the learners would be more motivated to learn. Lee et al. (1999), for example, state that introducing the use of the internet in teaching is a means for learners to get the maximum benefits. The English teacher wanted to enrich the learners' English lessons because he felt that the learners were not motivated. As a result he decided to design a project which combined both computers and English study.

From the findings presented above, it is clear that the aim of the project was not attained. There 
was a very negative attitude towards the project, more than half the learners complaining that they disliked the project. Twenty-two (61\%) of the 36 boys and girls ( 4 had not started) believed that the project did not enrich their literary experience of the film. From the data collected, there appear to be two main reasons for this negative attitude. Firstly, there was a lack of enthusiasm from the English teachers. If the teachers were not excited about the project, one could hardly expect the learners to be motivated and enthusiastic. Related to this is the lack of communication between the English and IT departments. This resulted in a lot of confusion for the learners: the instructions kept changing, and the English teacher would tell the class one thing and then the IT teacher would tell the class something else. As a result, many leamers did not know what was required of them. The two departments only sat down together several weeks after the project had been given to the Grade $10 \mathrm{~s}$.

The second reason for the negative attitude is probably that the allocated time for the learners to do their projects was not during their regular English periods, but during their IT period; a time when many of the learners would usually e-mail, surf the Web for things that interested them or play games. They regarded it as a free period, and so many of the learners resented having to do an academic project during this time. In the classes which were observed, the learners, especially the boys, fooled around and then rushed the project at the end, cutting and pasting any old pictures just so that they would get a mark. They therefore learned very little, if anything at all.

The Shakespeare in Love project was a good idea. However, it turned out to be an unproductive learning experience for the learners. This does not mean, of course, that other similar internetbased projects in other contexts and with a different set of teachers and learners will also not be productive. The literature review at the start of this article points this out very clearly. Nevertheless, the findings of the case-study described in this article suggest that in this particular context the project was not successful. Augmented teaching perhaps turned out to be unproductive teaching.

In order for such a project to work in the future, more planning needs to be done, and this planning needs to be done in detail and finalised before the project outline is issued to the learners. It might also be a good idea for all the teachers involved with the project to meet together right from the start. By doing so, they will all know what is wanted and expected of each other and the learners. Communication is the key element, especially when there are more than a few people involved. Learners need to be briefed appropriately and those providing technical and content support must be involved at the start and throughout the duration of the project. It would also be a good idea if the learners could use one of their English classes as a 'project period'. This way, they would not feel that they have to work during their free time, thus resenting the work.

For many South African teachers and learners, using computers in language education is a new, unfamiliar activity (and, admittedly, still unattainable for most). Initial research endeavours, therefore, should explore actual cases of how computers (including the internet) are used in language classes, very much like the case study reported in this article. Descriptions of effective use, and failures, will contribute to our understanding of the practice and will also be useful for further computers-in-education curriculum development. 


\section{REFERENCES}

BARRON, A AND K IVERS. 1998. The internet and instruction: Activities and ideas. Englewood: Libraries Unlimited.

BETT, S, D FRENCH, G FARR \& L HOOKS. 1999. Augmenting traditional teaching with Internet-based options. In French, D, C Hale, C Johnson \& G Farr (Eds.), Internet based learning. London: Kagan Page: 47-62.

BOWERS, R. 1999. Talking shop: People, machines, and language teaching. English Language Teaching Journal, 53(4):300-308.

CARRIER, M. 1991. Simulations in English language teaching: A cooperative approach. Academic Search Elite. EBSCO Publishing. Date accessed: 23 April 2000. http://www.epnet.com/ehost/login.html (Also published in Simulation \& Gaming, 22(2):pp 224.)

CARRIER, M.1997. ELT online: The rise of the Internet. English Language Teaching Journal, 51(3):277-301.

CRAMPTON, M. 1999. This blessed plot. Unpublished Manuscript.

DAVIES, L. 1998. Ideas for collaborative e-mail and WWW language learning. Date accessed: 23 April 2000. http://www.beavton.k12.or.us/vince/stuemail/davies.htm

FRENCH, D, C HALE, C JOHNSON \& G FARR. (Eds). 1999. Internet based learning. London: Kagan Page.

GANDERTON, R. 1996. Internet tools in language teaching. Date accessed: 23 April 2000. http://www.cltr.uq.oz.au:8000/ rogerq/langnet.html

LEE, S, S ARMITAGE, P GROVES \& C STEPHENS. 1999. Online teaching: Tools and projects. Date accessed: 23 April 2000. http://info.ox.ac.uk/jtap/reports/teaching/html

McCORMACK, C \& D JONES. 1998. Building a web-based education system. New York: John Wiley \& Sons.

McKENZIE, C. 2000. Homepages: Built in motivation. English Teaching Forum, 38(1):34-38.

MEAGHER, M. 1995. Learning English on the Internet. Academic Search Elite. EBSCO Publishing. Date accessed: 23 April 2000. http://www.epnet.com/ehost/login.html. (Also published in Educational Leadership, 53(2):228.)

RELAN, A \& B GILLANI. 1997. Web-based instruction and the traditional classroom: similarities and differences. In Khan, B (Ed.), Web-based instruction. Englewood Cliffs: Educational Technology Publications: 41-46.

SERIM, F AND M KOCH. 1996. Netlearning: Why teachers use the Internet. Sebastopol: Songline Studios. 
SPERLING, D. 1997. The internet guide for English language teachers. Upper Saddle River: Prentice-Hall.

\section{Biographical Note}

Samantha Hannig is a postgraduate student in the Department of English Language and Linguistics at Rhodes University with an interest in the use of computer technology in the language classroom. Gary Barkhuizen lectures in the Department of English Language and Linguistics at the University of Rhodes. His research interests are in teacher education and learner perceptions of their learning environment, and he has published in TESOL Quarterly, International Journal of the Sociology of Language, and Linguistics and Education. 


\section{Appendix A}

\section{Questionnaire: Shakespeare in Love internet project}

Where applicable, please tick the appropriate box.

\section{Age? \\ 2. Male $\square \quad$ Female $\square$}

3. Do you do Computer Studies as a subject at school? Yes $\square$ No $\square$

4. If No, have you done it in the past? Yes $\square$ No $\square$

5. Are you interested in Computers and the Internet in general? Yes $\square$ No $\square$

6. If Yes, how do you make use of Computers? (e.g. Software programmes, surfing the Web, e-mail, computer games? Specify which aspects you use frequently.)

7. In one sentence, describe what you thought of the movie Shakespeare in Love

8. What was your initial opinion of the Shakespeare in Love IT project?

9. How many periods a week were allocated to the project?

10. After having started your project, did your initial feelings change? Yes $\square \quad$ No $\square$

11. If Yes, how? If No, why not?

12. Did you use your time constructively during the allocated periods?

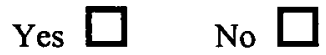

Give a reason for your answer. 
13. How did you feel about the structure of the project in relation to other English projects that were not IT related? (e.g. not enough guidelines, too much independent research, too structured.)

14. Would you say that this IT project enriched your literary experience of your film study? Yes $\square \quad$ No $\square$

15. Give a reason for your answer. 